\title{
Socio-economics of using poles for constructing houses in the Congo Basin
}

\author{
Julius Chupezi TIEGUHONG \\ Beyond Timber Project, Biodiversity International, P.O. Box 2008 Messa, Yaoundé, Cameroon. \\ Tel.: +237 22238562/+237 75622222, Fax: +27-33-2606005; E-mail: chupezi@yahoo.co.uk
}

\begin{abstract}
Increasingly, poor people in sub-Saharan Africa are affected by three dimensions of poverty, these being hunger, thirst and living without a decent shelter. This study focused on the latter dimension of poverty and examined the use of housing materials in villages surrounding the Lobeke National Park (LNP) in the Eastern Region of Cameroon. In total 1980 houses were surveyed, of which 1343, 602, 19, 14 and 2 were built with planks, saplings and poles, tree bark and thatch, respectively. The houses were roofed with thatch (1715), aluminum sheets (225) or leaves (40). Variations were observed among ethnic groups regarding their preferences for housing materials. Further analysis concentrated on houses built with poles harvested from indigenous forests. There were six categories of houses built with varying quantities of poles and thatch. Villagers used between 370000 and 614000 poles (58-97 times more than the number of trees cut for timber in 2006) to build houses in 14 villages surrounding the LNP. This is particularly destructive because such houses are short-lived, requiring a repetitive harvesting of poles for renovations every 5-15 years. With the removal of poles by adjoining villagers, the structure of indigenous forests and composition can be seriously changed, thus, compromising the possibility of supply future forest goods and services. Therefore, following a rapidly increasing population, there is an urgent need to empower local communities to improve their housing habits by promoting building materials alternative to poles harvested from indigenous forests.
\end{abstract}

(C) 2011 International Formulae Group. All rights reserved.

Keywords: Deforestation; Forest conservation; Housing materials; Poverty; Pygmies

\section{INTRODUCTION}

Inadequate housing is a big challenge in the rural areas of the developing world that clearly needs urgent actions. Over 3 billion people live in such areas, 1.5 billion of them on less than US\$ 2 a day. In the tropics alone, forests and woodlands provide housing materials for over 800 million rural poor people (World Bank, 2007). In the rainforest of Africa over 500000 indigenous people live in very poor quality houses, whereby they face multiple threats to their lives including poor health and security standards (FPP, 2005).

The Congo Basin forests cover 228 million ha making this the second largest area of tropical rainforest after the Amazonian region (de Wasseige et al., 2009). This forest straddles six countries in differing proportions, these being Cameroon (11.8\%), the Central African Republic (3.4\%), the Republic of Congo (12.4\%), the Democratic 
Republic of Congo (53.4\%), Equatorial Guinea (1.3\%) and Gabon (17.7\%) (CBFP, 2006). About 18.5 million ha or $10.2 \%$ of the Congo Basin forests are classified as national parks or other protected areas (CBFP, 2006). Over 88.5 million people live in the Congo Basin (2006), resulting in an average population density of 22.2 inhabitants $\mathrm{km}^{-2}$ and Gross Domestic Products (GDP) of US\$ 411 per capita (FAO, 2009). About 62\% of the population lives in rural areas and depends on forest resources to meet their daily needs for revenue, food, health and shelter (Tieguhong et al., 2009; Sandker et al., 2009). With an annual growth rate of $2.5 \%$, the Congo Basin's population might double in less than 30 years with possible negative effects on the natural resources of the region they depend on. This suggests that urgent actions are required by governments, development and conservation organisations, and local authorities to reduce forestdependencies of the growing population in the region. Such actions, if implemented, would contribute to the continuous existence of the admirable forests in the Congo Basin.

So far, no studies have been conducted in the Congo Basin to show the magnitude of natural resource utilisation for housing. In some previous studies authors dwelled on the identification and characterisation of local housing materials with little attention paid to their actual quantity (FAO, 1987; Profizi, 1983; Motte, 1982; Pelissier, 1980). Moreover, no attempts were made in these studies to examine the socio-economic circumstances and environmental consequences of harvesting materials from indigenous forests for building temporary shelters that are generally dingy, squalid, short-lived and unsafe for humans. This clear deficiency has been addressed in this study which attempts to quantify the local needs for traditional building materials in villages surrounding the Lobeke National Park in the Eastern Province of Cameroon. It is anticipated that the results will lead to policy reflections and actions for improving housing qualities and improved conservation of forests in the Congo Basin at the same time.

\section{MATERIELS AND METHODS \\ Study area}

The Tri-National Park (TNS) is located at the heart of the Congo Basin and consists of the Lobeke National Park (LNP) in the southeastern corner of Cameroon, the DzangaNdoki National Park (DNNP) in the Central African Republic (CAR) and the NouabeleNdoki National Park (NNNP) in the Republic of Congo. The TNS covers $28000 \mathrm{~km}^{2}$ including a $21000 \mathrm{~km}^{2}$ peripheral zone comprising logging concessions, trophy hunting and communal hunting zones, agroforestry areas and other activities of local people. On the LNP side of the TNS, there are six hunting zones superimposed within five logging concessions, covering a total area of 354928 ha. In June 1998, the government of Cameroon declared the LNP as a "Gift to the Earth" covering an area of 217854 ha. The park is rich in forest resources and wildlife on which generations of indigenous communities have depended for centuries and millennia. Among the 14 villages surrounding the LNP, five (Libongo, Koumela, Mambele, Zega, Socambo) were randomly selected for the survey of housing and construction materials (Figure 1). In 2004, the total estimated human population for the entire study area was about 26000 people: 12000 living in rural villages and 14000 people living in three adjoining logging towns (Kika, Libongo and Lokomo) (MINEF, 2004). The local people include the Baka Pygmies, the Bangando and the Bakwele as well as a number of immigrant people. Human activities in the region include timber extraction, non-timber resource exploitation, hunting, subsistence agriculture and construction of houses. The biological value of the region is characterized by a great variety of animals such as forest elephants (Loxodonta africana cyclotis), western lowland gorillas (Gorilla gorilla), chimpanzees (Pan troglodytes), bongos (Tragelaphus euryceros), duikers (Cephalophus spp.), sitatungas (Tragelaphus spekei), forest buffaloes (Syncerus caffer nanus), and numerous species of birds 


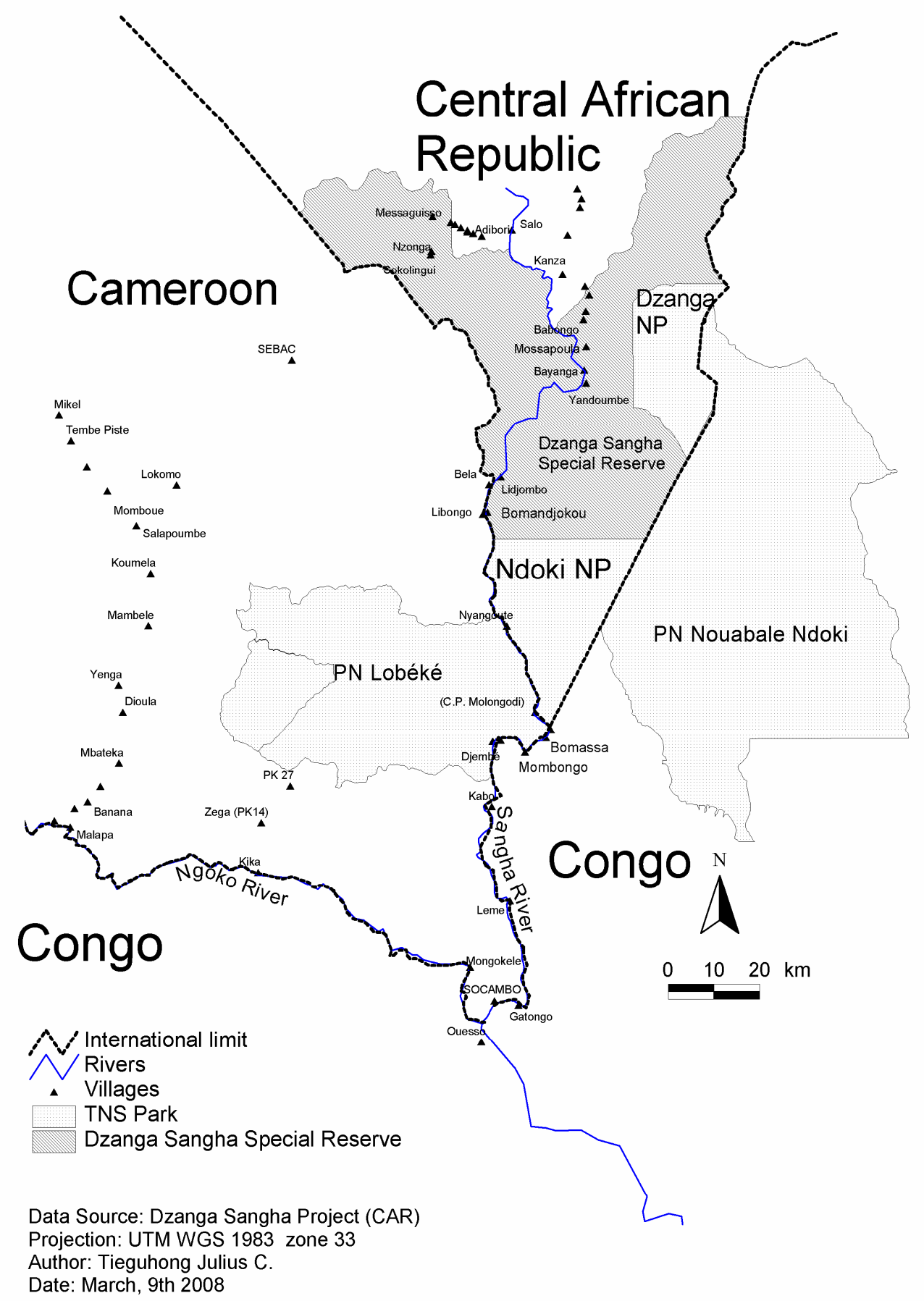

Figure 1: Map of the Tri-National Park showing study villages around the Lobeke National Park. 
including the African grey parrots (Psittacus erithacus) (MINEF, 2004). There are 764 plant and 45 mammal species, excluding rodents (MINEF, 2004). Major stakeholders in this area are local communities, administrative and municipal authorities, delegates from the Ministry of Forestry and Wildlife (MINFOF), and representatives from the Worldwide Fund for Nature (WWF) and the German Technical Cooperation (GTZ).

\section{Data collection and analysis}

Stratified random sampling was applied to collect data in the study area. The fourteen villages neighbouring the Lobeke National Park were stratified into two groups comprising (a) three logging towns with sawmills and (b) 11 rural villages without sawmills. For the first stratum one town was randomly selected and for the second, four villages were randomly selected. This gave a total of five villages for the survey with households constituting the basic survey units. A village census approach (small survey of all households in selected villages) was employed to get key demographic information and specific data on housing materials (PEN, 2007). This also served to introduce inhabitants to the research project and to explain the goals of a more detailed household survey. Data collection tools included a structured questionnaire of twelve questions, focus group interviews, field observations and literature search. The structured questionnaire included variables such as village name, ethnic groups of inhabitants, household head, gender, number of wives/husbands, number of children and their sex, household size, types of building and roofing materials. Data was entered into excel sheets, checked and analyzed using the pivot table for descriptive statistics and chi-square tests. In-depth statistical analyses were carried out by using econometric models in order to get the differences and similarities among villages in terms of housing habits. This study also focused on providing the determinants of the choices of one category of housing material over another. This was realized by using logit models as the dependent variables were qualitative and dichotomous. Logit models make links between independent variables and the probability of the dependent variable taking the value 0 or 1 (Mukherjee et al., 1998). The logit models were applied in the Statistical Package for Social Sciences (SPSS) Version 12 in Microsoft Windows 2003 interface.

\section{Logit models}

In the econometric models, the dependent variables consisted of the specific types of building or roofing material used by individual households. Each dependent variable was dichotomised into binary choice questions of either using a specific material for building houses (Yes) or not using that material (No). It was supposed that the use of a specific building or roofing material could be explained by social factors like the village type, household's ethnic group, social status (size and number of houses owned), etc. After running the logit model, significant variables were considered as the determinants (source of motivation) to use specific types of building and/or roofing materials. The formulation of the model for each building or roofing material is shown below.

Let $\boldsymbol{j}$, be the building material factor taking values from 1 to 5 ( 1 for poles, 2 for planks, 3 for leaves, 4 for bark, and 5 for thatch) and $\boldsymbol{k}$ be the roofing material taking values from 1 to 3 ( 1 for aluminum sheets, 2 for leaves, and 3 for thatch). The equations of the logit models for each housing or roofing material are provided below:

$$
\begin{aligned}
& \operatorname{Ln}\left(P_{i}^{j} /\left(1-P_{i}^{j}\right)\right)=\alpha_{1} X_{1}+\alpha_{2} X_{2}+\alpha_{3} X_{3}+\alpha_{4} X_{4}+\alpha_{5} X_{5}+\varepsilon_{i} \\
& \operatorname{Ln}\left(P_{i}{ }^{k} /\left(1-P_{i}{ }^{k}\right)\right)=\beta_{1} X_{1}+\beta_{2} X_{2}+\beta_{3} X_{3}+\beta_{4} X_{4}+\beta_{5} X_{5}+\varepsilon_{t}
\end{aligned}
$$


where:

$\mathrm{P}_{\mathrm{i}}^{\mathrm{j}}$ is the probability for a household $\mathrm{i}$ to use the housing material $\mathrm{j}$

$\alpha_{1}$ are coefficients whose values and signs determine the influence of variables on the preference for housing material

$\mathrm{P}_{\mathrm{i}}^{\mathrm{k}}$ is the probability for a household to use the roofing material $\mathrm{k}$

$\beta_{\mathrm{i}}$ are coefficients whose values and signs determine the influence of variables on the preference for roofing material

$\mathrm{X}_{\mathrm{i}}$ are expected independent variables

$\varepsilon_{\mathrm{i}}$ is the error term

Subscript $\mathrm{i}$ denotes the $\mathrm{i}$ observation in the sample

In these types of models, the interpretation of results is made with the signs of the observed coefficients and the Odds ratios (ORs) (Desjardins, 2005). OR is the ratio of the odds defined with respect to the dependent variable (dichotomous variable) at different values of explanatory variables (Mukherjee et al., 1998). An odds ratio greater than one indicates an increasing probability to use a specific type of building/roofing material. The converse holds true for an odds ratio less than one.

\section{Definition of dependent variables}

The dependent variables refer to various types of construction materials described below:

i. Poles - tree stems or their sections obtained by harvesting young trees with stem diameters of $32 \mathrm{~cm}$ or less at $1.3 \mathrm{~m}$ above ground (dbh). This definition includes saplings which are usually of dbh less than 20 $\mathrm{cm}$ diameter. Saplings and poles are potential mature trees and thus represent good candidates for future recruitment and regeneration of forests (Nwoboshi, 1982);

ii. Planks - primary processed timber, which, in this study, are mainly residuals of sawnwood produced at sawmills. These are sometimes given to local people free of charge for the construction of their houses. Materials commonly used include slabs, off-cuts and deformed planks;

iii. Leaves - harvested from plants belonging to the Maranthaceae family which are used mostly by the Baka Pygmies to build houses locally known as Mungulus; iv. Bark - is the outer layer of tree stems, limbs and twigs of woody plants;

v. Thatch - woven or netted products from raffia palm petioles usually 2-3 m long, used as roofing material with a lifespan of less than three years;

vi. Aluminum sheets - a common aluminum product used in the form of corrugated sheets for roofing houses. It is far more expensive than local roofing materials.

Theoretical relationships between each explanatory variable and its impact on a choice of construction materials are described as follows:

i. Village (rural village or small town) considered to be the lowest administrative unit in the region, under the auspices of a village leader called Chief (PEN, 2007). It was supposed that the village of residence of a given household head could be linked to the likelihood of using specific housing and roofing materials available in the area as the types of houses found in the villages are linked to the general level of their development. Thus, the expected sign of influence in the logit model can be positive or negative;

ii. Ethnic group - ethnicity can determine the type of housing material used due to different social experiences. The study area is composed of people from multi-ethnic backgrounds. Therefore the expected sign in the logit model can be positive or negative depending on social preferences;

iii. Household size varied from 1 to 29 persons with a mean of 5.91 persons and standard deviation of 3.06 persons. Household 
size was 6.1 persons per household in Libongo and 5.81 in the other villages. It was supposed that bigger households could be associated with more permanent structures because more free labour can be provided. A positive sign was expected;

iv. Population structure and gender records showed that females headed only $4.5 \%$ of households whilst the rest of them $(95.5 \%)$ were headed by males. The sex of the household head could positively influence the housing and roofing quality because male headed households could have higher physical energy exertion to enter the forest and harvest the best available local materials. The expected sign should be positive. Almost $65 \%$ of the people were classified as "youth" with almost an equal proportion of boys and girls;

v. Number of houses owned per household varied from one to eight with a mean of 1.8 houses and standard deviation of 0.89 houses. The number of houses owned by a household could positively influence the material used for housing. The number of houses is an indication of wealth, which could positively influence the type of housing material used.
Identifying and estimating number of poles

With regards to identifying and classifying the different species of trees used, the indigenous knowledge was indispensable and the local names in Bangando/Baka dialects were registered. These names were cross-checked with the help of forest technicians and an available checklist of plants for the region (Tieguhong and Ndoye, 2007).

A random sample of 36 houses constructed with poles was used to research the amount of the building materials. The number of poles and thatch components were counted in each of the 36 houses. The number of rooms per house was also recorded. This led to the classification of houses by their size (number of rooms) and the amount of construction and roofing materials. This data was later extrapolated into all of the 14 villages in the region. Three methods were employed to extrapolate the total number of poles used for building houses in the 14 villages around the LNP.

The first method was based on extrapolating the number of poles used in the five villages surveyed, to all of the 14 villages in the region according to the formula below:

$\mathrm{TS}_{14}=\frac{\mathrm{TS}_{5} \cdot 14}{5}$

where

$\mathrm{TS}_{14}=$ Total number of poles used as housing material in 14 villages around LNP

$\mathrm{TS}_{5}=$ Total number of poles used as housing material in the 5 villages surveyed.

The assumption was that all the villages had homogenous structures, which in reality was not the case. The 14 villages had different structures as they were divided into logging towns with sawmills and rural villages without sawmills.
The second method was based on extrapolating the number of poles used by the population of the five villages for the whole population of all the 14 villages according to the formula below: 


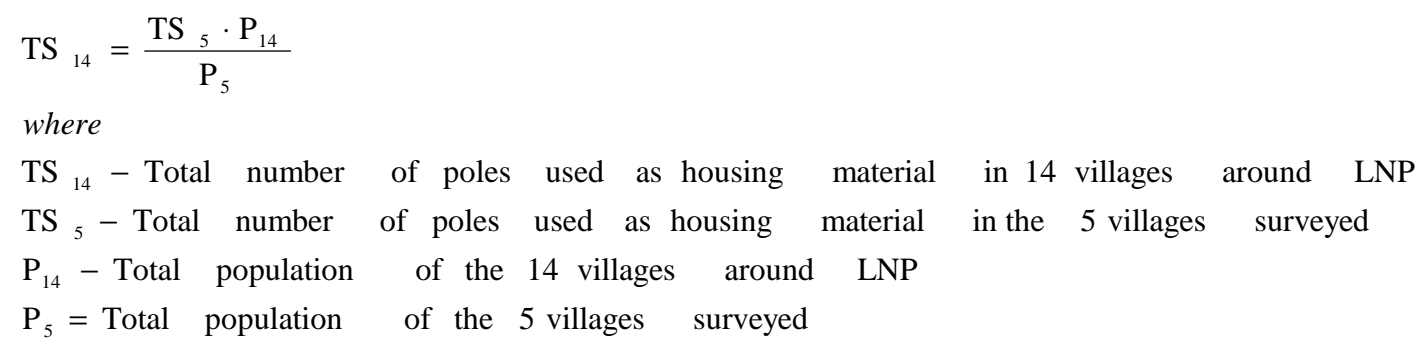

The assumption was that the village population size was directly and significantly linked to the number of houses constructed. However, the villages had different demographic characteristics with logging towns having higher average household size than rural villages. Moreover, the proportion of pole houses in the logging towns was far lower than in rural villages.
The third method involved taking into account (i) population size, (ii) village structures (rural villages or logging towns) and (iii) a range of social characteristics in each type of village such as household size, number of houses per household, percentage of pole houses.

The equations of the third method are specified as follows:

$$
\mathrm{TS}_{14}=\sum_{\mathrm{i}=1}^{2} \mathrm{NHS}_{\mathrm{i}} * \mathrm{ASpH}_{\mathrm{i}} \quad \text { where }\left\{\begin{array}{l}
\mathrm{THo}_{\mathrm{i}}=\mathrm{P}_{\mathrm{i}} / \mathrm{AHsize}_{\mathrm{i}} \\
\mathrm{TH}_{\mathrm{i}}=\mathrm{THo}_{\mathrm{i}} * \mathrm{ANHpHo}_{\mathrm{i}} \\
\mathrm{NHS}_{\mathrm{i}}=\mathrm{TH}_{\mathrm{i}} * \mathrm{SH}_{\mathrm{i}}
\end{array}\right.
$$

where:

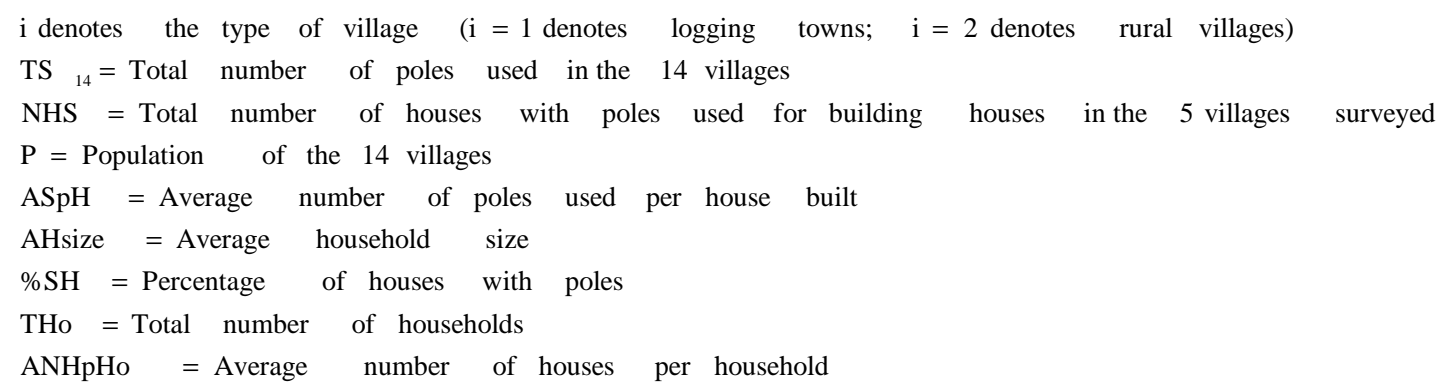

\section{RESULTS}

Distribution of population, houses and building materials

The total population of the five villages surveyed was 6486 inhabitants belonging to 37 ethnic origins in Cameroon and three foreign nationalities. This ethnic diversity was integrated into four major groups to facilitate the analysis. These groups were: Bangando, Baka Pygmies, non- indigenous Cameroonians and foreigners representing $19 \%, 28.3 \%, 51.8 \%$ and $0.9 \%$ of the population, respectively. Libongo was found to be the most populated village with $62.2 \%$ of the total population followed by Mambele (17.8\%), Koumela (12.7\%), Socambo (3.8\%) and Zega (3.5\%). A chisquare test showed that the ethnic background was highly statistically dependent $\left(\mathrm{df}=12, \chi^{2}=\right.$ $2019, \mathrm{p}<0.001$ ) on the village (location). 
The household size varied from one to 29 persons with a mean of 9.91 persons and a standard deviation of 3.06. The number of houses owned per household varied from one to eight with a mean of 1.8 houses and a standard deviation of 0.89 . The number of wives per household varied from none for single men to five for some married men with a mean of 1.1 wives and a standard deviation of 0.54 . The number of children varied from none to 13 . The overall population was particularly youthful with $64.5 \%$ youths (less than 18 years of age) of which $33.1 \%$ were boys and $31.4 \%$ girls. The mean number of boys and girls per household were 1.97 (standard deviation $=1.79)$ and 1.84 (standard deviation $=1.74$ ), respectively, giving a sex ratio of 1.07 for the study villages.

A total of 1980 houses were surveyed. The Bangando, Baka Pygmies, nonindigenous Cameroonians and foreigners owned $18.1 \%, 28.0 \%, 53.0 \%$ and $1.0 \%$ of the houses, respectively. In terms of the distribution of houses in the villages, Koumela, Libongo, Mambele, Socambo and Zega had $14.5 \%, 61.9 \%, 16.0 \%, 4.2 \%$ and $3.3 \%$ of the houses respectively.

Five types of building materials were recorded in the study area: poles, planks, leaves, thatch and bark were used for constructing $30.4 \%, 67.8 \%, 1.0 \%, 0.1 \%$ and $0.7 \%$ of the houses, respectively (Table 1 ).

In a sample of 1980 houses in five villages around the LNP, 1343 houses were built with planks from sawmills, 602 with poles, 19 with Thaumatococcus daniellii leaves of (Maranthaceae) popularly known as Mungulus, two with thatching materials and 14 with tree bark. Most of the houses built with planks were found in Libongo, a logging town where people make use of sawmill residues such as slabs, waste wood and offcuts for construction. The proportion of houses built with poles was $30.4 \%$ (602 out of $1980)$ in all the five villages surveyed. Over 92\% of houses in Libongo (logging town) were built with planks. In the other four villages less than $29.2 \%$ of the houses were constructed with planks. Poles and other local materials, such as leaves and bark, accounted for $70.8 \%$ of houses in those villages (Koumela, Mambele, Socambo and Zega). The proportion of houses built with poles in four villages excluding Libongo was $66.8 \%$. Pole houses represented only $7.9 \%$ of the houses in Libongo. A chi-square test showed that the non-indigenous inhabitants used far more frequently sawmill off-cuts (956 houses) than the other building materials (112 houses) while the opposite was true for the indigenous people. The differences between the two groups were highly significant $\left(\mathrm{df}=12, \chi^{2}=\right.$ $542, \mathrm{p}<0.001)$. The distribution of houses by the ethnic groups and roof material types is shown Table 2.

Among the 1980 study houses $86.6 \%$, $11.4 \%$, and $2.0 \%$ houses were roofed with thatch, zinc and leaves of Maranthaceae, respectively. A chi-square test showed that people from different ethnic backgrounds had significantly different preferences $\left(\mathrm{df}=6, \chi^{2}=\right.$ $101.4, \mathrm{p}<0.001$ ) of roofing materials. This was further tested by using the logit analysis.

\section{Choice of building materials: the logit analysis}

The variable gender was excluded from the logit models as there were no significant ( $\mathrm{p} \geq 0.05$ ) preferences of building materials by males or females. No models were tested for bark or thatch as the house building materials because $99 \%$ of the respondents rejected their use for building houses. Therefore, three models were tested for house building materials (planks, poles and leaves) and three others for roofing materials (zinc, thatch and leaves). For each of these, dichotomous response variables were cross-classified in multidimensional contingency tables with explanatory variables. The explanatory variables were: location (village name), ethnicity, gender, household size and number of houses per household. Table 3 provides results of the logit analysis.

When the use of poles was analysed, the model explained $60 \%\left(\mathrm{R}^{2}=0.6\right)$ of the variance for building houses. This meant that the explanatory variables were strongly linked 
to the dependent variable (use of poles). The log-likelihood $(L R=798.1)$ was far higher than the theoretical Chi-square of 18.3 ( $d f$ $=10 ; \alpha=0.05$ ), meaning that the model was significant at the 5\% level. The model had a high predictive power of $83.1 \%$. Four social variables (village location (or name), ethnic group, household size and a number of houses owned by individual households significantly determined the likelihood of using poles for building houses. The model demonstrated that people living in Koumela and coming from Baka ethnic group, with many children $(\beta=$ 0.22 ) and possessing a few houses are the most likely ones to use poles for house building. Households in Libongo have 6.9\% less probability to choose poles as housing material than households of Socambo. On the other hand, households of Koumela have $2.35 \%$ higher probabilities than those of Socambo to have a pole house. Ethnic groups were significantly and positively linked to the probability of having a pole house. Baka Pygmies were most likely to use poles for building their houses with $12.23 \%$ higher probability than e.g. foreigners.

The model on the use of planks was also significant with the log likelihood ratio (LR) of 687.2 which was higher than the Chisquare of $18.3 \quad(d f=10 ; \alpha=0.05)$. The explanatory power of the model was high as indicated by the goodness of fit statistics $\left(R^{2}=\right.$ 0.657). Therefore, the explanatory variables predicted $84 \%$ of the variance. The model demonstrated that people living in Libongo or Mambele, having a high household size and more than one house were most likely to use planks to build their houses (Table 3). Those living at Zega and Koumela coming from Baka were less likely to use planks as building materials.

For using leaves as building materials, the model explained $96 \%\left(R^{2}=0.96\right)$ of the variance of the dependent variable. The model was significant, as the log likelihood ratio of 138.6 was higher than the theoretical Chisquare of $18.3(d f=10 ; \alpha=0.05)$. The model demonstrated that people living in Libongo, Mambele or Koumela, coming from the
Bangando ethnic group with a small household size were less likely to use leaves as building materials, while people belonging to the Baka ethnic group opted for leaves as the construction material (Table 3).

The model on the use of zinc as roofing material explained $64 \%\left(R^{2}=0.64\right)$ of the variance of the dependant variable. The model was significant as the log likelihood of 797.21 was by far higher than the theoretical Chisquare of $18.3(d f=10 ; \alpha=0.05)$. The model demonstrated that people living in Mambele ( $p>0.05$ ) were more likely to use the zinc as roofing material. Household from the Baka, Bangando and the non-indigenous Cameroonian were less likely to use zinc as roofing material (Table 3 ).

Using the leaves as a roofing material was explained in $92 \%\left(R^{2}=0.92\right)$. The observed log likelihood of 236 was greater than the theoretical Chi-square of 18.3 ( $d f$ 10; $\alpha=0.05$ ). The model showed that the people living in Mambele, Libongo or Koumela, coming from the Bangando or non indigenous Cameroonian ethnic groups were less likely to use leaves as roofing material (Table 3). Therefore, the only obvious ethnic group with high likelihood to use leaves as roofing materials were the Baka Pygmies.

Thatch analysis yielded a model which explained $64 \%\left(R^{2}=0.64\right)$ of the variance of the dependant variable with a log likelihood of 800 compared to the theoretical Chi-square of $18.3(d f=10 ; \alpha=0.05)$. The model demonstrated that people living in Koumela, coming from Bangando, Baka, and nonindigenous Cameroonians were more likely to use thatch as roofing materials. This likelihood was observed to increase with an increasing number of owned houses (Table 3 ).

A summary of the result of the logit analysis with regards to the likelihood of using specific building materials by inhabitants of the villages is shown in Table 4.

\section{Assessing the local needs for poles}

A description of "traditional" housing materials can be found in some botanical studies (Profizi, 1983; FAO, 1987). The 
information on the plant species that are used and the methods of house construction can also be found in anthropological studies (Pelissier, 1980; Motte, 1982; FAO, 1987). Some interesting information can be gleaned from socio-economic studies and surveys, which recorded housing types usually as indicators of wealth (Gartlan, 1987). However, no information was published on the quantities of materials used for house construction in the Congo Basin.

The focus of this study, therefore, was on the quantities of building materials used to build the 602 study houses which were constructed by using poles of various tree species and roofed with thatch. In the assessment of these housing materials a total of 36 randomly identified houses were examined in a greater detail. The 36 houses were classified into six size categories based on different requirements for the number of poles and the amount of thatch required for their construction:

Category 1: 17 six-bedroom houses made of 350 poles and 90 thatch components;

Category 2: 34 five-bedroom houses 300 poles and 80 thatch components;

Category 3: 67 four-bedroom houses 280 poles and 70 thatch components;

Category 4: 100 three-bedroom houses 254 poles and 62 thatch components;

Category 5: 167 two-bedroom houses 242 poles and 60 thatch components;

Category 6: 217 one-bedroom houses 145 poles and 54 thatch components.

By extrapolating the data collected from the 36 sample houses, it was found that 132189 poles and 36878 thatch components of 3982824 raffia palm petioles (Raphia spp.) were used to build the 602 study houses popularly known as poto-poto houses (Table 5). Such houses have a life span varying from five years for non-durable poles to fifteen years for poles extracted from slower decomposing tree species. House durability also depends on regular replacing of decayed thatch-roofs, usually every 2-3 years. Desirable stem characteristics for poles required by the villagers were straightness, strength, bifurcation above $2.0 \mathrm{~m}$ height and high natural durability. Durability was reported as the most important characteristic for selecting admirable species of trees.

These numbers when projected for the 14 villages surrounding the LNP show the impact of housing habits on the regeneration of the Congo Basin forests. The third method of the three methods proposed gave the most realistic results because it took into consideration the structure of the villages, the distribution of the house types and the population distribution and its housing habits. This method showed that 614389 poles were used compared to the usage of 369988 and 529695 poles defined with the first and second methods, respectively. A repetitive harvesting of such high numbers of poles for building houses in and around the protected areas in Cameroon alone could have serious environmental impacts on the forest regeneration and its composition especially with the growing population in the region.

Moreover, the continuous use of poles for housing might have also implications for getting desirable timber species by timber companies. Timber harvesting and sales are the economic pillars of many countries in the region. Logging companies exploited the five forest management units surrounding the LNP. In 2006 a total of 6343 trees where harvested in the region representing a volume of $120517 \mathrm{~m}^{3}$ or averaging $19 \mathrm{~m}^{3}$ per tree (Table 6).

In economic terms, poles and thatch components are collected locally at low cash cost compared to substitutes such as cement blocks and zinc roofing. Using bricks made of compacted clay was resisted for economic reasons. The unit prices of a pole and a $3.0 \mathrm{~m}$ long thatch were US\$ 0.2 and US\$ 0.4 , respectively. This means that the construction of the 602 poto-poto houses could cost the inhabitants of the study villages US\$ 26439 for getting the poles and US\$ 14751 for the thatching materials. These estimated costs did not include the cost of other materials such as twines and rattan used for cross-fastening the poles, the labour of owners and their friends helping with the construction work. 
Table 1: Distribution of houses by types of the building materials and ethnic groups in the study area in 2006.

\begin{tabular}{lccccccc}
\hline \multicolumn{1}{c}{ Ethnic groups } & poles & planks & leaves & thatch & bark & Total & \% \\
\hline Bangando $^{1}$ & 164 & 190 & 2 & 0 & 2 & 358 & 18.1 \\
Baka Pygmies & 330 & 197 & 14 & 2 & 11 & 554 & 28.0 \\
$\begin{array}{l}\text { Non- } \\
\text { indigenous }^{2}\end{array}$ & 105 & 940 & 3 & 0 & 1 & 1049 & 53.0 \\
Foreigners $^{3}$ & 3 & 16 & 0 & 0 & 0 & 19 & 1.0 \\
Total & 602 & 1343 & 19 & 2 & 14 & 1980 & 100 \\
$\%$ of all & 30.4 & 67.8 & 1.0 & 0.1 & 0.7 & 100 & \\
\hline
\end{tabular}

${ }^{1}$ Bangando group comprised the Bangando and Bakwele.

2 Non-indigenous Cameroonians included Abakoum, Anglophones (Bantu people form the northwest and southwest provinces of Cameroon), Badjoue, Bafia, Bakoko, Bamileke, Bamoun, Banen, Banvele, Bassa, Gbaya, Beti (Ewondo, Bulu), Bikele, Bobilis, Bokare, Djem, Douala, Essele, Haoussa, Kako, Kepere, Konabembe, Kako, Kepere, Konabembe, Maka, Mbang, Mbimo, Mezime, Mponpong, Ngoumba, Pol, Yabassi, Yambassa, Yanguere and Yebekolo.

${ }^{3}$ Foreigners were mainly from Congo, Senegal and Mali.

Table 2: Distribution of houses by types of the roofing materials and ethnic groups in the study area in 2006.

\begin{tabular}{lccccc}
\hline Ethnic groups & Zinc & Thatch & Leaves & Total & \% \\
\hline Bangando & 52 & 303 & 3 & 358 & 18.0 \\
Baka Pygmies & 52 & 470 & 30 & 552 & 27.9 \\
Non-indigenous & 109 & 935 & 7 & 1051 & 53.1 \\
Foreigners & 12 & 7 & 0 & 19 & 1.0 \\
Total & 225 & 1715 & 40 & 1980 & 100 \\
\% of all & 11.4 & 86.6 & 2.0 & 100 & \\
\hline
\end{tabular}

\section{DISCUSSION}

In the study area, the Bangando and the Baka Pygmies are the indigenous people while the other groups are immigrants (MINEF, 2004). The indigenous people represented $47.3 \%$ of the population, while the immigrants represented $52.7 \%$. This result compares well with the other estimates of $50 \%$ indigenous people and $50 \%$ of immigrants (MINEF, 2004). The influx of immigrants is associated with numerous economic activities, such as logging, mining, sport hunting, tourism, petit-trading and poaching, that generally require some capital investment, specialised skills and knowledge. These qualities are generally lacking among the indigenous people due to the lack of education. Apart from Koumela that is $12 \mathrm{~km}$ away from the a secondary school in Salapoumbe, the other villages are between 70 to $230 \mathrm{~km}$ away from the nearest secondary schools. Rural schools have usually poor infrastructure and poor staffing. The nearest high school is in the regional capital some 150 $\mathrm{km}$ from the Koumela and $400 \mathrm{~km}$ from Socambo. The nearest university is in the capital city of Yaounde, some $800-1000 \mathrm{~km}$ from the study villages. 
Table 3: Results of the logit analysis on preference of building materials in the study area in 2006.

\begin{tabular}{|c|c|c|c|c|c|c|c|c|c|c|c|c|c|c|c|c|c|c|}
\hline \multirow{3}{*}{$\begin{array}{l}\text { Independent } \\
\text { variables }\end{array}$} & \multicolumn{9}{|c|}{ House Building Materials } & \multicolumn{9}{|c|}{ Roofing Materials } \\
\hline & \multicolumn{3}{|c|}{ Planks } & \multicolumn{3}{|c|}{ Poles } & \multicolumn{3}{|c|}{ Laves } & \multicolumn{3}{|c|}{ Zinc } & \multicolumn{3}{|c|}{ Thatch } & \multicolumn{3}{|c|}{ Leaves } \\
\hline & $\mathrm{B}$ & $\mathbf{p}$ & OR & $\beta$ & $\mathbf{p}$ & OR & $\beta$ & $\mathbf{p}$ & OR & $\beta$ & $\mathbf{p}$ & OR & $\beta$ & $\mathbf{p}$ & OR & $\beta$ & $\mathbf{p}$ & OR \\
\hline Village & & 0.000 & & & 0.000 & & & 0.000 & & & 0.000 & & & 0.005 & & & 0.000 & \\
\hline Mambele & 0.771 & 0.040 & 2.16 & -0.14 & 0.682 & 0.87 & -2.04 & 0.001 & 3496 & 1.02 & 0.023 & 2.78 & -0.19 & 0.589 & 0.82 & -2.30 & 0.000 & 0.10 \\
\hline Libongo & 3.09 & 0.000 & 22.0 & -2.67 & 0.000 & 0.07 & -3.40 & 0.000 & 0.033 & -0.20 & 0.650 & 0.82 & 0.55 & 0.118 & 1.73 & -2.45 & 0.000 & 0.09 \\
\hline Zega & -1.98 & 0.008 & 0.14 & 0.61 & 0.251 & 1.84 & -19.7 & 0.997 & 0.003 & -19.1 & 0.997 & 0.00 & 19.9 & 0.997 & 457 & -20.6 & 0.997 & 0.00 \\
\hline Koumela & -1.04 & 0.020 & 0.35 & 0.86 & 0.038 & 2.35 & -2.09 & 0.006 & 0.008 & -0.27 & 0.610 & 0.76 & 1.01 & 0.040 & 2.74 & -2.62 & 0.001 & 0.07 \\
\hline Gender & 0.831 & 0.061 & 2.30 & -0.30 & 0.432 & 0.74 & -18.2 & 0.997 & 0.279 & 0.42 & 0.299 & 1.52 & -0.04 & 0.936 & 0.97 & -18.0 & 0.997 & 0.00 \\
\hline Ethnic group & & 0.000 & & & 0.000 & & & 0.001 & & & 0.000 & & & 0.031 & & & 0.000 & \\
\hline Bangando & -1.29 & 0.096 & 0.28 & 1.22 & 0.100 & 3.38 & -3.05 & 0.001 & 0.005 & -2.33 & 0.000 & 0.10 & 1.07 & 0.010 & 2.92 & -1.81 & 0.048 & 0.16 \\
\hline Baka & -2.84 & 0.000 & 0.06 & 2.51 & 0.001 & 12.2 & -1.45 & 0.017 & 13280 & -2.54 & 0.000 & 0.08 & 0.83 & 0.026 & 2.29 & 0.44 & 0.465 & 1.55 \\
\hline Pygmies & -0.08 & 0.917 & 0.92 & 0.15 & 0.841 & 1.16 & -3.24 & 0.001 & 0.082 & -2.26 & 0.000 & 0.10 & 1.10 & 0.004 & 3.00 & -1.47 & 0.039 & 0.23 \\
\hline Other Cam & 0.40 & 0.002 & 1.50 & -0.07 & 0.030 & 0.94 & 0.54 & 0.000 & 0.000 & 0.057 & 0.597 & 1.06 & 0.47 & 0.001 & 1.59 & -0.45 & 0.174 & 0.64 \\
\hline House numbers & 0.10 & 0.004 & 1.10 & 0.22 & 0.034 & 1.25 & -0.11 & 0.013 & 1.510 & 0.039 & 0.177 & 1.04 & -0.05 & 0.085 & 0.95 & -0.01 & 0.903 & 0.99 \\
\hline Household size & -0.60 & 0.455 & 0.55 & -0.68 & 0.374 & 0.51 & -19.7 & 0.998 & 0.000 & -0.01 & 0.988 & 0.99 & -1.50 & 0.018 & 0.22 & -18.7 & 0.998 & 0.00 \\
\hline
\end{tabular}

Constant

( $\alpha, \beta$ - coefficients, $\mathrm{p}$ - probabilities, OR - odds ratios). 
J. C. TIEGUHONG / Int. J. Biol. Chem. Sci. 5(6): 2464-2480, 2011

Table 4: A summary on building material preferences by various villages in the study area in 2006.

\begin{tabular}{|c|c|c|c|c|c|c|}
\hline Object type & Building materials & Koumela & Libongo & Mambele & Zega & Socambo \\
\hline \multirow[t]{3}{*}{ Housing } & Poles & ++ & - & $=$ & $=$ & $=$ \\
\hline & Planks & - & ++ & + & $=$ & $=$ \\
\hline & Leaves & $=$ & - & $=$ & $=$ & $=$ \\
\hline \multirow[t]{3}{*}{ Roofing } & Zinc & $=$ & $=$ & ++ & $=$ & $=$ \\
\hline & Leaves & - & - & - & + & ++ \\
\hline & Thatch & ++ & + & $=$ & $=$ & $=$ \\
\hline
\end{tabular}

("-" the likelihood lower than the reference, "=" the likelihood and the reference equal, "+" the likelihood higher than the reference, "++" the highest likelihood).

Table 5: Characteristics of the 602 houses built with poles and the required amount of material components found around the Lobeke National Park (Cameroon).

\begin{tabular}{|c|c|c|c|c|c|c|}
\hline $\begin{array}{l}\text { No of bedrooms } \\
\text { in a house }\end{array}$ & $\begin{array}{l}\text { No. of houses per } \\
\text { category }\end{array}$ & $\begin{array}{l}\text { No. of poles per house } \\
\text { in each category }\end{array}$ & $\begin{array}{l}\text { Total no. of } \\
\text { poles }\end{array}$ & $\begin{array}{c}\text { No. of thatch per } \\
\text { house in each category }\end{array}$ & $\begin{array}{c}\text { Total no. } \\
\text { of thatch } \\
\text { components }\end{array}$ & $\begin{array}{c}\text { Total no of palm } \\
\text { petioles }\end{array}$ \\
\hline 6 & 17 & 350 & 5950 & 90 & 1530 & 165240 \\
\hline 4 & 67 & 280 & 18760 & 70 & 4690 & 506520 \\
\hline 3 & 100 & 254 & 25400 & 62 & 6200 & 669600 \\
\hline 2 & 167 & 242 & 40414 & 60 & 10020 & 1082160 \\
\hline Total & 602 & - & 132189 & - & 36878 & 3982824 \\
\hline
\end{tabular}


Table 6. Forest management units (FMU), number of trees and timber volume harvested around the Lobeke National Park (Cameroon) in 2006.

\begin{tabular}{lcc}
\hline FMU & Number of trees & Timber volume ${\left(\mathbf{m}^{3}\right)}^{\mathbf{3}}$ \\
\hline 10012 & 1190 & 26250 \\
10064 & 2469 & 46367 \\
10011 & 279 & 3865 \\
10013 & 669 & 13303 \\
10063 & 1736 & 30732 \\
Total & 6343 & 120517 \\
\hline
\end{tabular}

Primary schooling, which is common in the region, can not enable the indigenes to compete with the non-indigenes for salaried jobs. Therefore they remain unemployed or are employed for menial jobs of lower pay that cannot pull them out of the poverty or enable them to send their children to higher educational centres in distant places. Added to the above is the fact that funding allocated to village communities, such as shares of revenues from logging companies or sporthunting concessions, are not equitably shared among the ethnic groups therefore the minorities get little or nothing to improve their standards of living (Sandker et al., 2009). According to Jackson (2004) the local dominant groups in terms of education and charisma are able to capture forest taxes and tourism revenues and are the main beneficiaries. The immigrants enter the region with modern ideas on capital accumulation, lobbying, business skills and a higher sense of security. The absence of moving out of their own surroundings makes it impossible for most of the indigenous people to understand the benefits of economic independence and living in decent and safe houses. Their hopes are merely lost, making them emotionally attached to forests to get materials for building shelters, good or bad in the sight of onlookers. In recent past, researchers and development workers had virtually overlooked problems related to housing standards in the region, which gives this study its pioneering status. It may also be observed that historically the Baka Pygmies dwelled on barter and exchanged with the other ethnic groups (Jackson, 2004) and only recently they have been introduced to the cash economy with a saving culture that is required for capital accumulation and investments for development ends. The above assertions are shared by the UN Committee on Economic, Social and Cultural Rights with concluding remarks that ethnic minorities such as the Baka Pygmies are severely marginalized in the areas of employment, health and education, and are usually considered socially inferior. Consequently they are deprived of full integration into society in terms of their economic, social and cultural rights (FPP, 2005).

The circumstances that entangle the indigenous people in poverty seem to have direct implications on the state of their housing. The poverty-stricken indigenous people build their houses with poles and roof them with thatch and leaves while the immigrants possess $90 \%$ of the houses built with planks. The major characteristics of the Bangando are that in addition to hunting and gathering, they possess a farming culture while the Baka Pygmies are more forest dependent. The Bangando are also dominant over the Baka Pygmies in terms of a higher political consciousness and power relations controlling the local economy (Jackson, 2004). This is reflected also in their better housing compared to the Baka who still build houses known as 'mungulus' by using leaves. Any policy conceived to discourage the local people from using poles for building houses should target the population of Koumela. Lessons drawn in Koumela should be used for 
possible applications in other villages. In a short term, logging companies could distribute sawmill residue, such as planks and slabs, to distant villages because the use of planks replaces the use of poles. Such an effort would have development and conservation benefits, securing quality trees for future harvesting in a mid-term.

In this paper, the assessment of building materials was mainly done for poles and thatch. The main reason for selecting poles as building materials was the understanding that poles are potentially mature trees with greater future economic and environmental benefits. In economic terms some of the saplings are of the highly soughtafter timber species. Examples include: Triplochiton scleroxylon (ayous) Mansonia altissima (bete), Entandrophragma utile (mboyo), Milicia excelsa (iroko), Staudtia kamerunensis (malanga), Diospyros iturensis (babango), Celtis adolfi friderici (kakala). A frequent harvesting of such trees at their juvenile stages reduces their contributions to the future stocks of valuable merchantable trees in the Congo Basin. Aside from the timber value, the ecological values of saplings that are allowed to grow into mature trees cannot be overemphasized. This is relevant in the light of the global understanding of the role of forests in carbon sequestration and maintenance of tropical biodiversity. Allowing saplings to grow to maturity would imply less deforestation, forest degradation and fragmentation. According to FAO (2009), primary forests are lost or modified at the rate of 6.0 million ha per year through deforestation or selective logging and that about $20 \%$ of emissions of greenhouse gases that contribute to global warming are caused by deforestation. Estimates by the World Bank (2007) showed that one hectare of intact rainforest stores 500 tons of carbon dioxide. With the price per stored ton averaging US\$ 20 in European markets the forest carbon reserves are worth US\$ 10000 per ha or US\$ 2280 billion when recalculated for the total forest area of 228 million ha in the Congo Basin. Thus, by assuming a 100 year rotation cycle, an annual sustainable value benefit from the $\mathrm{CO}_{2}$ storage can be estimated at US\$ 22.8 billion in the region.

If the status-quo of housing habits and population upsurge remain unchanged, then the future impact of cutting saplings for building houses could become devastating for the Congo Basin's forests. This situation is stressing for more integrated actions by ecologists, economists and development agencies. Alternative materials for building houses in the Congo Basin could include bricks made of compacted clay. If every household in the five villages studied is provided with one moulder, it would cost about US\$ 500000 for 2000 households or US\$ 1107500 for the fourteen villages around the LNP. With regard to roofing materials, subsidises could be provided to get more durable materials. Alternative to brick houses, wooden construction materials could be produced in fast growing timber plantations of desirable tree species. A serviceable life of wood could be prolonged by preservation treatments. This option would add value to the carbon storage initiatives and could be co-financed by development agencies. This scenario could be implemented if the G8 member nations are truly determined to assist developing countries in reducing emissions from deforestation (G8 Summit, 2007).

\section{Conclusion and recommendations}

According to Poore and Thang (2000), poverty remains the greatest threat to tropical forests and the key element for their protection lies in ensuring that their management remains profitable to all concerned. To what extent has this advice been taken into consideration by the tropical forest management in Africa? Increasing numbers of poor people in sub-Saharan Africa are still being affected by three dimensions of poverty such as hunger, thirst and living without a decent shelter (Commission for Africa, 2005). This research dwelled on the latter dimension of poverty and examined the environmental, social and developmental 
impacts in the villages bordering the LNP, East Province of Cameroon. The state of housing was exceptionally poor and the indigenous populations depended on building materials harvested from indigenous forests. Forest villages generally lack basic infrastructure and services while the indigenous populations were generally marginalized. As the population increases its impact on the indigenous forests will worsen making their further use unsustainable. Squalid tropical forest housing is seen as a product of failed conservation policies, underfunding and neglect by the overall political will. Policy changes and implementation are needed to improve housing qualities and the general living conditions of the forestdependent poor.

This improvement could be achieved in the following ways:

- develop and promote more durable building materials including treated wood;

- establish plantations of desirable species of trees for house construction;

- promote using building bricks manufactured from compacted clay;

- re-distribute sawmill residues for common benefit.

Without stringent actions to improve the livelihoods of the people in the Congo Basin in a way that would reduce outright forest-dependency, the rich forest resources of this region might be lost in the foreseeable future. One way of reducing forestdependency would be to provide better housing for the poor. If alternative construction materials are not provided then the poor will continue harvesting saplings for constructing houses, causing forest fragmentation and degradation. A better understanding of the use of local housing materials should be obtained through further research on:

- the abundance and availability of building materials in the forest;

- the impact of sapling harvesting on the regeneration of desired forest species;

- the need for local building materials at the regional level (Congo Basin at large);
- selection, breeding, silviculture and management of desired species of trees in forest plantations;

- the effects of gender, age, main occupation and distance to forests on the choice of building materials.

\section{ACKNOWLEDGEMENTS}

We are deeply indebted to Victor Amougou and the field enumerators, for assisting in data collection. The warm welcome and collaboration offered by the local chiefs is greatly appreciated. Guy-Paulin Tekombong, Eric Kamgnia, Elise Tokou, Bruno Bokoto, and Paolo Cerutti are thanked for sharing with us their ideas and knowledge that was invaluable in analysing complex datasets and producing maps. We acknowledge and thank the French Cooperation, the International Foundation of Science (IFS) and the African Forestry Research Network (AFORNET) for funding all field research work, as well as CIFOR and the University of KwaZulu-Natal for efficiently managing the funds.

\section{REFERENCES}

Commission for Africa. 2005. Our Common Interest. Report of the Commission for Africa. Commission for Africa. 462 pp.

CBFP (Congo Basin Forest Partnership). 2006. The Forests of the Congo Basin. State of the Forest. CBFP; 256p. ISBN: 978907827016.

Desjardins J. 2005. L'analyse de régression logistique. Tutorial in Quantitative Methods for Psychology, 1(1): 35-41.

De Wasseige C, Devers D, Marcken P, Eba'a RA, Nasi R, Mayaux P. 2009. The Forests of the Congo Basin. State of the Forest 2008. Yaoundé, Cameroon: Office des publications de l'Union Européenne.

FAO. 2009. State of the World's Forests 2005. FAO, Rome. 152p.

FAO. 2007. Facts and Figures. FAO. http://www.fao.org/forestry/site/28679/en /Last, visited 02 July 2007. 
FAO. 1987. Forestry for local community development. FAO Forestry paper 7, Rome, pp 33-51.

FPP (Forest Peoples Programme). 2005. Indigenous Peoples and United Nations Human Rights Treaty Bodies: A Compilation of Treaty Body Juris prudence 1993-2004, 290p.

G8 Summit. 2007. Growth and responsibility in the world economy. Summit Declaration (7 June 2007), 37p.

Gartlan S. 1987. Korup regional management plan: conservation and development in the Ndian Division of Cameroon. World Wide Fund for Nature (WWF) and Earth Life, Godalming, England (mimeograph).

Jackson D. 2004. Implementation of international commitments on traditional forest related knowledge: Indigenous peoples' experiences in Central Africa. Forest People Programme (FPP), 100p.

MINEF (Minsitry of Environment and Forestry). 2004. Plan d'Aménagement du Parc National de Lobeke. MINEF, 81p.

Motte E. 1982. Les plantes chez les pygmées Aka et les Monzombo de Lobaye (Centre Afrique): étude ethnobotanique comparative chez les chasseurs-cueilleurs et les pêcheurs-cultivateurs dans un même milieu végétal. Société d'Etudes Linguistiques et Anthropologiques de France (SELAF), Paris, France.

Mukherjee C, White H, Wuyts M. 1998. Econometrics and Data Analysis for Developing Countries, Mosley P (Ed.) Routledge: New York; 496p.

Nwoboshi LC. 1982. Tropical Silviculture: Principles and Techniques. Ibadan University Press : Ibandan; 103.
Pelissier P. 1980. L'arbre dans les paysages agraires de l'Afrique Noire. Cahiers d'ORSTOM, ORSTOM, Paris, France. Série Sciences Humaines, 17(3r4):127137.

PEN (Poverty Environment Network). 2007. PEN Technical Guidelines, Version 3, CIFOR. July 2007. P.36.

Poore D, Thang HC. 2000. Review of progress towards the Year 2000 Objective. ITTO, Yokohama.

Profizi JP. 1983. Les palmiers raphia du sud Benin: utilisations actuelles et potentielles. Notes Africaines 178.

Sandker M, Campbell BM, Nzooh Z, Sunderland T, Amougou V, Defo L, Sayer J. 2009. Exploring the effectiveness of integrated conservation and development interventions in a Central African forest landscape. Biodiversity Conserv., 18: 2875-2892.

Tieguhong JC, Ndoye O, Vantomme P, Grouwels S, Zwolinski J, Masuch J. 2009. Coping with crisis in Central Africa: enhanced role for non-wood forest products. Unasylva, 233(60): 49-54.

Tieguhong JC, Ndoye O. 2007. The Impact of Timber Harvesting in Forest Concessions on the Availability of Non-Wood Forest Products (NWFP) in the Congo Basin. FAO Forest Harvesting Case Study 23. ISBN: 978-92-5-105709-4.

World Bank. 2007. At loggerheads? In Agricultural Expansion, Poverty Reduction and Environment in the Tropical Forests, Chomitz KM, Buys P, Giacomo de Luca, Thomas TS, WertzKanounnikoff S (Eds). World Bank; 308 p. 